\title{
Congress touts budget boost for NASA and the NSF
}

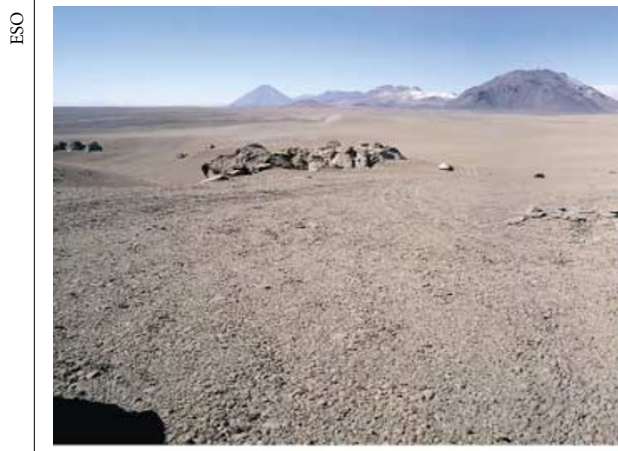

What's in the stars? The future of ALMA and its site on a Chilean plateau remain uncertain.

Tony Reichhardt, Washington

One small step in the federal budget process last week was a giant leap forward for the funding prospects for non-biomedical research next year in the United States.

A key congressional subcommittee voted on 10 July to boost funding for the National Science Foundation (NSF) and NASA for the 2002 fiscal year, which begins on 1 October. The move is the latest and largest of a series of congressional actions to restore research funds that were omitted from President Bush's budget request in April (see Nature 410, 731;2001).

Scientists have been grumbling for months about the White House's proposed $1.3 \%$ increase for the NSF. Now the House subcommittee that oversees the foundation's budget says that the increase should be $9.5 \%$ instead, bringing the total NSF budget to $\$ 4.84$ billion.

The full House appropriations committee was due to take up the measure this week, as was a Senate appropriations panel chaired by Barbara Mikulski (Democrat, Maryland). Mikulski is a supporter of NASA and has said she favours increased funding for the NSF.

Budget deliberations will continue into September, when the House and Senate will reconcile their spending bills. But the marker laid down by the House panel augurs well for both agencies' prospects, their supporters say.

Every directorate in the NSF saw its allocation raised by the subcommittee. And at least one project — the High-performance Instrumented Airborne Platform for Environmental Research (HIAPER), an aircraft for conducting atmospheric science to be operated by the National Center for Atmospheric Research in Colorado - was saved from elimination. The House panel added \$35 million for the project, which had been given nothing in Bush's request. Funding for Major Research Instrumentation, which supplies university researchers with

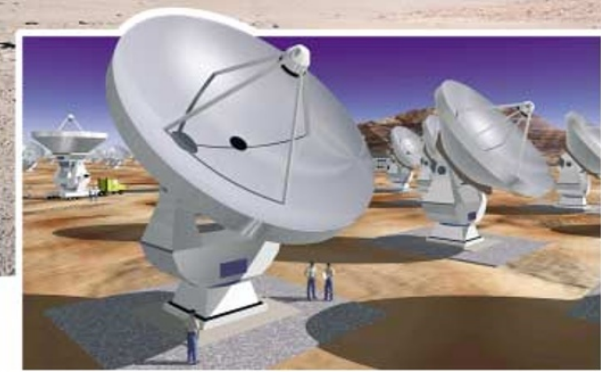

advanced lab equipment, was restored to last year's level of $\$ 75$ million, where the White House had asked for only $\$ 50$ million.

Still uncertain is the fate of the Atacama Large Millimeter Array (ALMA), a 64-antenna telescope planned to be operational by 2010. The United States, Europe and Japan expect to spend a combined $\$ 600$ million on ALMA, which will be located in Chile. But the NSF, which is funding the project on the US side, has been slow to commit construction funding for it. Astronomers were alarmed this spring when the White House moved funds for ALMA out of the NSF's Major Research Equipment account-traditionally where large construction projects are handled. The House panel moved the funds back, but kept ALMA's budget at $\$ 9$ million. This means it would remain stuck in the design phase - unless the Senate adds more funds.

NASA got a raise from the subcommittee that was $\$ 415$ million over the presidential request, bringing the total for 2002 to $\$ 14.9$ billion. But the space agency's biggest fiscal headache, the International Space Station, remains unresolved. The House panel added $\$ 310$ million to the White House request for the station, bringing it to $\$ 1.8$ billion. Most of that would go to resurrect work on a crew return vehicle, which Bush scrapped but which many scientists say is needed to support an active research programme.

But the rise hardly makes a dent in the cost overrun - $\$ 4$ billion and growing - that prompted NASA managers to propose deep cuts in research aboard the station (see Nature 410, 399; 2001). Life scientists planning biological studies are aghast at NASA's plans to cancel key pieces of lab equipment in order to trim its research budget. Among the casualties are facilities for holding animals, plants and cell cultures. In a draft report accompanying its recommended budget last week, the House panel seemed as frustrated as the scientists, and has begun an investigation into the cost overruns.

\section{Physical sciences lose ground as US shifts towards biology}

Jonathan Knight

The number of graduate students enrolling in physical sciences in the United States is still falling sharply, despite an expansion in the government's overall research budget, according to the National Research Council (NRC).

In its latest study, the NRC finds that recruitment has dropped in chemistry, physics, mathematics and engineering as federal funding shifts towards the life sciences. For example, the number of fulltime graduate students in physics fell by $22 \%$ between 1993 and 1999, whereas the number in medical sciences rose by $41 \%$.

Some observers expected increases in overall research funding to stop or slow the decline, says Stephen Merrill, staff director of the NRC study. "There was an expectation that the rising tide was lifting all boats," he says.

But an NRC panel chaired by Dale Jorgenson, an economist at Harvard University, found that the rise in total research investment after 1997 had failed to reverse the overall trend. The panel noted that federal funding for physical sciences declined by $18 \%$ in constant dollars from 1993 to 1999, whereas funding for life sciences rose by $28 \%$.

Michael Lubell, a physicist at the City College of New York and head of public affairs at the American Physical Society, predicts that effects of the shift will be felt gradually, as the quality of the workforce declines. "As researchers retire from the national labs and academia, it will get harder to replace them with high-quality people," he says.

i www.nationalacademies.org/step

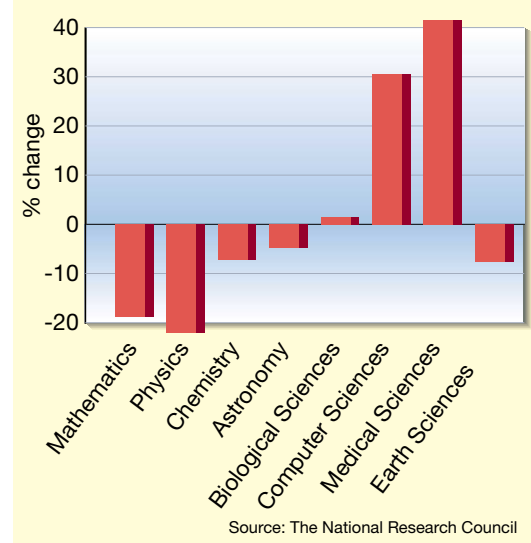

Percentage change in the number of full-time graduate students, United States, 1993-99. 